\title{
The Factor Related to Mother's Motivations in Carrying out the Circumcision of the Female Children in a Teuk Jawo Village Baiturrahman Sub District, Banda Aceh in 2014
}

\author{
Marniati ${ }^{*}$, Rahmayani, and Ayuwari Yunita
}

\begin{abstract}
Circumcision is the activity carried out to remove the partial foreskin of penis. The preliminary survey result of 15 mothers that were carried out the circumcision to their female children mention that 7 mothers carried out the circumcision because of the culture/tradition from generation to the generation, 5 mothers brought their children because of the family supports. There are 121 female children that are $0-5$ years old in Ateuk Jawo Village. The objective of this research is to detect the factors that affect the mothers' motivations in carrying out the circumcision to female children in Ateuk Jawo Village, Baiturrahman Sub District, Banda Aceh. The methodology used in this research is analytical descriptive with 121 population of people. The samples in this research are 55 people. The sampling technique is purposive sampling. The data was collected by distributing the questionnaires. This research was conducted in Ateuk Jawa Village, Baiturrahman Sub Village, Banda Aceh on July 2014. The results of this research mention that $\mathrm{Chi}$-Square tests show that from 28 respondents who chose the culture were not affected to the low motivations of the mothers in carrying the circumcision, there were 16 respondents $(57.1 \%)$ with the value of $p=0.003(p<0.05)$. From the 32 respondents who chose the family supports were higher affected of the mothers' motivations, there were 26 respondents $(81.2 \%)$ with the value of $p=0.004(p<0.05)$. The last was from the 25 respondents who chose the religion factor were the most affected of the mothers' motivations, there are 21 respondents $(84 \%)$, with the value of $\mathrm{p}=0.010(\mathrm{p}<0.05)$. This research concluded that there are the relations among culture, family supports and religions factor that were affected the mothers' motivations in carrying out the female children circumcision. It is recommended to the pregnant women to improve the knowledge about the circumcision to their female children later.
\end{abstract}




\section{Introduction}

Circumcision practice to the female children becomes the tradition in the particular community groups. The main objective is to control the sexual libido of the women. There is an assumption that the dirt on the clitoris can cause the women sexual libido become uncontrollable. whereas the circumcision practice is harmful to physical health and sexual psychic of the women [5].

The update estimation data from UNICEF mention that about 120 millions of the female children and the women had been carried out the female circumcision in 29 countries. Based on these current trends, as many as 30 million female children under 15 years old still have the risk to be carried out the circumcision. The consolidation Programme between the Funds of the United Nations Population (UNFPA) and UNICEF on the female children circumcision has been conducting the progress in preventing female children and female future generations from the circumcision practice. The latest estimation data of the UN General Committee that had been ratified with the unanimous vote on December 2012 was to urge the member countries in intensifyng efforts to eliminate the whole female circumcision practice [13]. The various type of the female circumcision practice, both symbolically and female genital mutilation/cutting practice is a form of discrimination and violence against women that have to be abolished. This activity is an arbitrary action against the female body integrity. When the country fails to effectively oppose this practice, it will encourage the public perceptions that the other person has the right to control the sexuality of a woman or female children [8].

The female children circumcision in Indonesia is carried out to 0-18 years old female depending on the local culture. The female circumcision generally is done to the baby after birth, $70 \%$ is in Java and Madura, $78 \%$ is in North Sumatra and 64\% is in West Sumatra, are carried out to under 1 year old and partly to $7-9$ years old [2].

The provision of female circumcision is arranged in Health Minister Regulation (Permenkes) No.1636 / 2010. This Permenkes mentioned that the definition of female circumcision is an activity that only scratching the skin that covers the front of the clitoris, without injuring the clitoris. Female circumcision can only be carried out by the medical officers such as Doctors, Midwives, and Nurses. In addition, the process of circumcision has to be done in the sterile place, room and equipment. Circumcision also has be carried out with adequate lighting and the availability of the clean flow [8].

The practice of female circumcision is expected that had been started since 4000 years ago, before the organized religion came. Anthropologists revealed that the practice of female circumcision had been popular in the ancient Egyptian community; this is evidenced by the pure discoveries. Some people consider that female circumcision is a tradition related to religion, so rise to the pro and contra. Female circumcision is also carried out in in 28 countries, mostly carried out in the most of African countries, partly in Asian, Latin America, North America and Europe Countries In Indonesia, mentioned that the tradition of female circumcision is a habit that came together of Islamic that continue and common happen since the ignorance period (Tonang, 2006).

Data of female circumcision in Indonesia is still very difficult to obtain. However, it does not mean that female circumcision is not carried out in Indonesia. The problem of female circumcision is a hidden problem because the prevalence is very big but not raised up. No complication reports because of the female circumcision activity in Indonesia, it is because there is lack of knowledge about the female reproductive organs or the shame culture and feeling fear to reveal the incidence of female circumcision (Juliansyah, 2009).

The female circumcision especially in Indonesia is most done as a aprt of the culture or tradition. At the beginning, it was only the community tradition, not religion. But when the 
religion meets the tradition, then it was given the response. The religion response that accommodated the tradition then become the culture (Meiwita, 2006).

The relatives can be the motivator to the parents, because by the supporting of the families/relatives to carry out the circumcision to the female childred, so that the mothers will do so to their daughters [9].

Based on the preliminary study that has been done in Ateuk Jawo Village, it was found that many mothers brought their daughters to have the circumcision practice. Even from the health factor, the female children circumcision is not allowed anymore because it will give the negative effects to the female children. The mothers said that the female children circumcision had been their tradition or habit since before.

From the preliminary study that has been done by the researcher on January $3^{\text {rd }} 2014$ in Ateuk Jawo Village, Baiturrahman Sub District, Banda Aceh, found that there the circumcision were carried out to 45 baby girls that had just been born by the midwife. According to preliminary survey result to 15 mothers that carried out the circumcision practice to their daughters, it was found that 7 mothers took the baby to have circumcision because of the culture/tradition from generation to generation, 5 mothers told that they took the babies because of the family supports. There are 121 female children that are $0-5$ years old in Ateuk Jawo Village.

From the above phenomena and background, the writers are interested in assessing "the Dari Fenomena dan latar belakang tersebut di atas, maka penulis tertarik untuk melihat "

What The Factors Related To Mothers' Motivations In Carrying Out The Circumcision Of The Female Children In Ateuk Jawo Village, Baiturrahman Sub District, Banda Aceh are"

Problem Finding

The problem finding in this research is how the The Factors Related To Mothers' Motivations In Carrying Out The Circumcision Of The Female Children In Ateuk Jawo Village, Baiturrahman Sub District, Banda Aceh are.

\section{Research Objectives}

\section{Main Objective}

To detect the factors that affects the mothers' motivations in carrying out the circumcision to female children in Ateuk Jawo Village, Baiturrahman Sub District, Banda Aceh.

\section{Special Objective}

a. To detect the relation between the culture and mother motivation in carrying out the circumcision to the female in Ateuk Jawo Village, Baiturrahman Sub District, Banda Aceh. b. To detect the relation between the family support and mother motivation in carrying out the circumcision to the female in Ateuk Jawo Village, Baiturrahman Sub District, Banda Aceh.

c. To detect the relation between the religion factor and mother motivation in carrying out the circumcision to the female in Ateuk Jawo Village, Baiturrahman Sub District, Banda Aceh.

\section{Research Benefits}

\section{1. to Puskesmas}

Improving the concept and reference about the female children circumcision and improving the health services especially in handling female children circumcision 


\section{2. to Respondents}

The result can be the suggestion and recommendation the pregnant women to improve the knowledge about the circumcision to their female children later.

\section{3. to Educational Institution}

To Improve the concept and reference in giving the guideline material of obstetrics and gynecology.

\section{4. to Researchers}

To improve the concept and reference about the female children circumcision so that the research can be continued by using the different variables.

\section{Concept Framework}

The research concept framework is the framework of the relation among the observed concepts and be measured through the research done. In this research, the researchers only want to detect the factors that affects the mothers' motivations in carrying out the circumcision to female children in Ateuk Jawo Village, Baiturrahman Sub District, Banda Aceh.

According to the $\mathrm{MOH}$ [8], factors that affected mothers' motivations in carrying out the circumcision to female children are because of three factors, they are: predisposing factors, enabling factors, attitudes, beliefs, moral/norms / culture, confidence, and capacity Enabling factor consists of the availability of health resources, reachable of health resources, government regulations, priorities and community commitment to health, and health counseling from health professionals, peers, teachers, employer/supervisor, health care providers, community leaders, and policy makers. / keputusan. But the researchers only want to focus on cultural factors, family support, and religion that have the huge relation to the female circumcision.

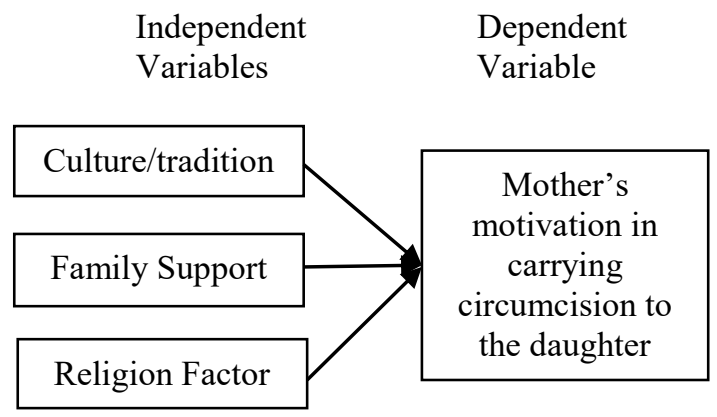

\section{Research Type}

This research is analytical descriptive with cross sectional study design that has the objective is to the factors that affects the mothers' motivations in carrying out the circumcision to female children in Ateuk Jawo Village, Baiturrahman Sub District, Banda Aceh.

\section{Population and Sample}

The population in the research is all mothers whose daughters are $0-5$ years old on January - December 2013. The total are 121 who living in Ateuk Jawo Village, Baiturrahman Sub District, Banda Aceh.

The sampling technique is Purposive Sampling means the samples are chosen based on the researchers considerations using the characteristics or features of the population known before (Notoatmodjo, 2005). The criteria are shown as below: 
a. Mothers whose daughters are 0-5 years old

b. Mothers that have capable in reading and writing

c. Mothers willing to be respondents

To determine the amount sample of the population, the researchers use the Slovin Formula (Notoatmodjo, 2005).

$n=\frac{\mathrm{N}}{1+\mathrm{N}\left(d^{2}\right)}$

then:

$n=\frac{121}{1+121(0,01)}$

$n=\frac{121}{1+1,21}$

$n=\frac{121}{2,21}$

$n=54,75$

$n=55$ sampel

Description:

$\mathrm{N}=$ The amount of population

$\mathrm{N}=$ The amount of sample

$\mathrm{d}=$ Precision determined of $10 \%$ with the confidence level of $90 \%(0,1)$

There are 55 samples calculating from the above formula.

\section{Location and Period of the Research}

The location of the research is in Ateuk Jawo Village, Baiturrahman Sub District, Banda Aceh. The research was conducted on July 2014.

\section{Data Collection}

a. Primary Data

The research is using the structured interview that the interview questions are detail compiled in a check- (Arikunto, 2006)

1. Data collection Part A is Demography data that is divided in 3 questions that is used as the opening interview questions. The demography data consists of: No, age of the respondent, and the last education of the respondent.

2. Data collection Part B is to assess the mother's motivation, culture factor, family support, and religion factor, by using the Guttman scale question that have 10 items for each question. For the positive statement, the answer of "yes" gets value 1 and "no" gets value 0 . For the negative statement, the answer of "yes" gets value 0 and "no" gets value 1 .

\section{Data Processing}

According to Notoatmodjo [9] data processing is done by some phases such as: Editing, Coding, Transferring, Tabulating. 
Captions should be typed in 9-point Times. They should be centred above the tables and flush left beneath the figures.

\section{Result Research}

\section{Unvaried Analysis}

a. Mothers' Motivations

Table 4.1: Distribution of Mothers' Motivations Frequency in Carrying Out the Circumcision to the Female Children Ateuk Jawo Village, Baiturrahman Sub District, Banda Aceh

\begin{tabular}{|c|c|c|c|}
\hline No & Live Motivation & $\mathrm{f}$ & $(\%)$ \\
\hline 1. & High & 35 & 63,6 \\
\hline 2. & Low & 20 & 36,4 \\
\hline & Total & 55 & 100 \\
\hline
\end{tabular}

Table 4.1 shows that from 55 respondents interviewed, the mother motivation in carrying out the daughter circumcision is high. There are 35 respondent $(63,6 \%)$ choose it.

b. Culture

Table 4.2: Distribution of Culture Frequency in Carrying Out the Circumcision to the Female Children Ateuk Jawo Village, Baiturrahman Sub District, Banda Aceh

\begin{tabular}{|c|c|c|c|}
\hline No & Culture & f & $(\%)$ \\
\hline 1 & Affected & 27 & 49,1 \\
\hline 2 & Not Affected & 28 & 50,9 \\
\hline & Total & 55 & 100 \\
\hline
\end{tabular}

Table 4.2 shows that from 55 respondents interviewed mentioned that the culture is not affected in carrying out the daughter circumcision. There are 28 respondent $(50,9 \%)$ choose it.

c. Family Support

Table 4.3: Distribution of Family Support Frequency in Carrying Out the Circumcision to the Female Children in Ateuk Jawo Village, Baiturrahman Sub District, Banda Aceh

\begin{tabular}{|c|l|c|c|}
\hline No & Family Support & f & $(\%)$ \\
\hline 1. & Support & 32 & 58,2 \\
\hline 2. & Not Support & 23 & 41,8 \\
\hline & Total & 55 & 100 \\
\hline
\end{tabular}

Table 4.3 shows that from 55 respondents interviewed mentioned that the family gives support in carrying out the daughter circumcision. There are 32 responden $(58,2 \%)$. 


\section{d. Religion Factor}

Table 4.4: Distribution of Religion Factor Frequency in Carrying Out the Circumcision to the Female Children in Ateuk Jawo Village, Baiturrahman Sub District, Banda Aceh

\begin{tabular}{|c|c|c|c|}
\hline No & Religion & f & $(\%)$ \\
\hline 1. & Affected & 25 & 45,5 \\
& & & \\
\hline 2. & Not Affected & 30 & 54,5 \\
\hline & Total & 55 & 100 \\
\hline
\end{tabular}

Table 4.4 shows that from 55 respondents interviewed mentioned that the religion is not affected in carrying out the daughter circumcision. There are 30 respondent $(54,5 \%)$ choose it.

\section{Bivariate Analysis}

a. The relation between culture and mother's motivation in carrying the daughter circumcision

Table 4.5: The Relation between culture and mother's motivation in carrying the daughter circumcision in Ateuk Jawo Village, Baiturrahman Sub District, Banda Aceh

\begin{tabular}{|c|l|c|c|c|c|c|c|c|}
\hline \multirow{2}{*}{ No } & \multirow{2}{*}{ Culture } & \multicolumn{3}{|c|}{ Mother's Motivation } & \multicolumn{2}{|c|}{ Total } & \multirow{2}{*}{ P-value } \\
\cline { 3 - 8 } & & \multicolumn{2}{|c|}{ High } & \multicolumn{2}{|c|}{ Low } & \multicolumn{2}{|c|}{} \\
\cline { 3 - 8 } & & $\mathrm{f}$ & $\%$ & $\mathrm{f}$ & $\%$ & $\mathrm{f}$ & $\%$ & \\
\hline 1 & Berpengaruh & 23 & 85,2 & 4 & 14,8 & 27 & 100 & \\
\hline 2 & Tidak Berpengaruh & 12 & 42,9 & 16 & 57,1 & 28 & 100 & 0,003 \\
\hline
\end{tabular}

Table 4.5 shows that from 28 respondents choosing that the culture is not affected show that the mother's motivation is low in carrying the daughter circumcision, there are 16 respondents $(57,1 \%)$. Meanwhile from 27 respondents choosing that the culture is affected show that the mother's motivation is high in carrying the daughter circumcision, there are 23 respondents $(85,2 \%)$.

After doing statistical test using chi-square test with a confidence level of $95 \%$ was obtained that $p$-value of 0.003 is smaller than $\alpha$-value of 0.05 . It can be concluded that there is a relationship between culture with mother's motivation in carrying out the female children circumcision in Ateuk Jawo Village, Baiturrahman Sub District, Banda Aceh.

b. The relation between family support and mother's motivation in carrying the daughter circumcision

Tabel 4.6: The Relation between family support and mother's motivation in carrying the daughter circumcision in Ateuk Jawo Village, Baiturrahman Sub District, Banda Aceh

\begin{tabular}{|c|l|c|c|c|c|c|c|c|}
\hline \multirow{2}{*}{ No } & \multirow{2}{*}{ Family Support } & \multicolumn{4}{|c|}{ Mother's Motivation } & \multicolumn{2}{|c|}{ Total } & \multirow{2}{*}{ P-value } \\
\cline { 3 - 9 } & & \multicolumn{2}{|c|}{ High } & \multicolumn{2}{|c|}{ Low } & \multicolumn{2}{|c|}{} \\
\cline { 3 - 9 } & & $\mathrm{f}$ & $\%$ & $\mathrm{f}$ & $\%$ & $\mathrm{f}$ & $\%$ & \\
\hline 1 & Support & 26 & 81,2 & 6 & 18,8 & 32 & 100 & \multirow{2}{*}{0,004} \\
\hline 2 & Not Support & 9 & 39,1 & 14 & 60,9 & 23 & 100 & \\
\hline
\end{tabular}


Table 4.6 shows that from 32 respondents choosing that the family support show that the mother's motivation is high in carrying the daughter circumcision, there are 26 respondents $(81,2 \%)$. Meanwhile from 23 respondents choosing that the family is not support show that the mother's motivation is low in carrying the daughter circumcision, there are 14 respondents $(60,9 \%)$.

After doing statistical test using chi-square test with a confidence level of $95 \%$ was obtained that $p$-value of 0.004 is smaller than $\alpha$-value of 0.05 . It can be concluded that there is a relationship between family support with mother's motivation in carrying out the female children circumcision in Ateuk Jawo Village, Baiturrahman Sub District, Banda Aceh.

c. The relation between religion factor and mother's motivation in carrying the daughter circumcision

Tabel 4.7: The Relation between religion factor and mother's motivation in carrying the daughter circumcision in Ateuk Jawo Village, Baiturrahman Sub District, Banda Aceh

\begin{tabular}{|c|l|c|c|c|c|c|c|c|}
\hline \multirow{2}{*}{ No } & \multirow{3}{*}{ Religion } & \multicolumn{4}{|c|}{ Mother's Motivation } & \multicolumn{2}{|c|}{ Total } & \multirow{2}{*}{ P-value } \\
\cline { 3 - 8 } & & \multicolumn{2}{|c|}{ High } & \multicolumn{2}{|c|}{ Low } & \multicolumn{2}{|c|}{} \\
\cline { 3 - 9 } & & $\mathrm{f}$ & $\%$ & $\mathrm{f}$ & $\%$ & $\mathrm{f}$ & $\%$ & \\
\hline 1 & Affected & 21 & 84 & 4 & 16 & 25 & 100 & \multirow{2}{*}{0,010} \\
\hline 2 & Not affected & 14 & 46,7 & 16 & 53,3 & 30 & 100 & \\
\hline
\end{tabular}

Table 4.7 shows that from 25 respondents choosing that the religion is affected show that the mother's motivation is high in carrying the daughter circumcision; there are 21 respondents $(84 \%)$. Meanwhile from 30 respondents choosing that the religion is not affected show that the mother's motivation is low in carrying the daughter circumcision, there are 16 respondents $(53,3 \%)$.

After doing statistical test using chi-square test with a confidence level of $95 \%$ was obtained that $p$-value of 0.010 is smaller than $\alpha$-value of 0.05 . It can be concluded that there is a relationship between religion factor with mother's motivation in carrying out the female children circumcision in Ateuk Jawo Village, Baiturrahman Sub District, Banda Aceh.

\section{Discussion}

1. The relation between the culture and Mother's motivation in carrying the circumcision to the female children.

Based on the research done result that from 28 respondents choosing that the culture is not affected show that the mother's motivation is low in carrying the daughter circumcision, there are 16 respondents $(57,1 \%)$. Meanwhile from 27 respondents choosing that the culture is affected show that the mother's motivation is high in carrying the daughter circumcision, there are 23 respondents $(85,2 \%)$.

After doing statistical test using chi-square test with a confidence level of $95 \%$ was obtained that $p$-value of 0.003 is smaller than $\alpha$-value of 0.05 . It can be concluded that there is a relationship between culture with mother's motivation in carrying out the female children circumcision in Ateuk Jawo Village, Baiturrahman Sub District, Banda Aceh.

According Syarifuddin (2009), culture comes from sangketa language (budhaya) is the plural of budhhi which means "mind" or "sense", all matters relating to the intellect. Culture is all of the complex parts, , in which consists of knowledge, belief, art, morals, habits acquired by the person as a member of community. Culture is a condition that describes the 
non-physical characteristics, such as moral, beliefs, attitudes, customs that are agreed by the community and is inherited from one generation to the next generation.

The circumcision has become the part of Indonesia Culture. In the rules of Islam, circumcision became one guidance that have to be executed by the followers, both men and women. On the recent development the male become more dominant to be the subject of the circumcision (Rahima, 2009).

Research has been done by Sartika (2011) about the factors affect the circumcision to the female children in Ladang Bambu Village, Medan Tuntungan Sub District. The results from the research mentioned that cultural factors affected in carrying out female children circumcision is 59 people $(95.2 \%)$. Based chi square test resulted that the value of $p=$ 0.08 . it was smaller than the value of $\alpha=0.05$, thus there is a relationship between culture with mother's motivation in carrying the circumcision to the female children.

According to the research assumption, there are relation between the culture and mother's motivation in carrying the circumcision to the female children, because the culture is a community tradition not religion, but when the religion meets the tradition, the religion gives the responds to accommodate the tradition or culture and then become the religion part. When the religion spreads to other area, the community practices the circumcision to the female children.

\section{The relation between the family support and Mother's motivation in carrying the circumcision to the female children.}

Table 4.6 shows that from 32 respondents choosing that the family support show that the mother's motivation is high in carrying the daughter circumcision, there are 26 respondents $(81,2 \%)$. Meanwhile from 23 respondents choosing that the family is not support show that the mother's motivation is low in carrying the daughter circumcision, there are 14 respondents $(60,9 \%)$.

After doing statistical test using chi-square test with a confidence level of $95 \%$ was obtained that $p$-value of 0.004 is smaller than $\alpha$-value of 0.05 . It can be concluded that there is a relationship between family support with mother's motivation in carrying out the female children circumcision in Ateuk Jawo Village, Baiturrahman Sub District, Banda Aceh.

Notoatmodjo et. al [9] mentioned that supporting factors from other party, for example, from husband/wife, parents, parents in-laws, friends, neighbors and midwives itself also affects the mother's attitude toward health service. Family can be the motivator for parents, because the most need other instruction very, but the family should also be able to explain about the benefits of circumcision so that motivation and knowledge can walk together. This motivation drives a person to behave and do the activity in order to reach the goals. Because in the fact the motivation is needed by the parents in order to encourage them in carrying out the circumcision to both male and female children [14].

Research conducted by Icha (2012), about "Factors Affecting Mother's Motivation in Carrying Out The Circumcision to the female children in Labuy Village, Baitussalam Sub District, Aceh Besar District indicated that the respondents who received family support proved to have high motivation in carrying out the circumcision of the female children as much as 16 respondents $(76.2 \%)$ compared to the respondents who have no family support proved to have low motivation in carrying out the circumcision of the female children as much as 5 respondents $(29.4 \%)$. Based on the chi square test, it was resulted that value of the $p=0.007$. it was smaller than the value of $\alpha=0.05$, thus there is a relationship between family support and mother's motivation in carrying out the female children circumcision.

According to the assumption of the researchers, there is the factor affected between the family support and mother's motivation in carrying out the female children circumcision, because by having the family support, the motivation is needed very much to facilitate 
someone in carrying out the circumcision both to the male and the female children, the circumcision can cause the improvement of the children fertility growth.

\section{The relation between the religion and Mother's motivation in carrying the circumcision to the female children.}

Based on the research conducted to 32 respondents choosing that the religion is affected show that the mother's motivation is high in carrying the daughter circumcision; there are 21 respondents $(84 \%)$. Meanwhile from 16 respondents choosing that the religion is not affected show that the mother's motivation is low in carrying the daughter circumcision, there are 16 respondents $(53,3 \%)$.

After doing statistical test using chi-square test with a confidence level of $95 \%$ was obtained that $p$-value of 0.010 is smaller than $\alpha$-value of 0.05 . It can be concluded that there is a relationship between religion factor with mother's motivation in carrying out the female children circumcision in Ateuk Jawo Village, Baiturrahman Sub District, Banda Aceh.

Islam teaches us to act proportionately. One is how we are used to controlling ourselves, including controlling our sexual libido. Female circumcision is expected to be a brake for women to control her sexual libido. Because according to the authentic history, women's desires are multiplied many times comparing to the males. In Islamic female circumcision is from the language khatana which means cut, the meaning in only cut/scratch the foreskin that cover the tip female genital to clean from dirty or called thahur which means cleaning (Umar, 2020).

According to the researchers assuming, there is relation between religion and mother's motivation in carrying out the female children circumcision, the religion is recommended to carry out the circumcision both to male or female, because the practice can control themselves including their sexual libido.

\section{Conclusion}

Based on the research done to 55 respondents summarize the statistical test as below:

1. There is the relation between the culture and mother's motivation in carrying out the female children circumcision in Ateuk Jawo Village, Baiturrahman Sub District, Kota Banda Aceh, with the $p$ value is 0,003 .

2. There is the relation between the family support and mother's motivation in carrying out the female children circumcision in Ateuk Jawo Village, Baiturrahman Sub District, Kota Banda Aceh, with the $\mathrm{p}$ value is 0,004 .

3. There is the relation between the religion factor and mother's motivation in carrying out the female children circumcision in Ateuk Jawo Village, Baiturrahman Sub District, Kota Banda Aceh, with the $\mathrm{p}$ value is value 0,010 .

\section{Recommendation}

\section{1. to Puskesmas}

It is estimated to improve concept and reference about the female children circumcision and improving the health services especially in handling female children circumcision

2. to respondent 
It is estimated that the research result can be as input and information to mothers whose daughters are $0-5$ years old carry out the female children circumcision.

3. to the educational institution

It is estimated to improve the concept and reference in giving generally guideline material in of obstetrics and gynecology.

4. to the next researchers

It is expected to improve the concept and reference about the female children circumcision so that the research can be continued with the different research variable.

\section{References}

1. Arikunto, S. Research Procedure of A Practice Approach. Jakarta: Rineka Cipta, (2006).

2. Azhari. A, Circumcision. www.arhamazhari.com, (2007)

(Viewed on February, 15 ${ }^{\text {th }}$ 2015)

3. Budiarto, Eko, Biostatic to Medical and Community Healthy, Penerbit EGC, Jakarta, (2006)

4. Budiharsana,M, dkk., "Research Reprot". Female Circumcision in Indonesia: Extend., Implication and Posible Intervention to Uphold Women's Helath Right, Population, Jakarta, (2009)

5. Khomar, MOH Policy of the Female Circumcision Medicalization.www.pdpersi.co.id./banne rbursa.jpg.(Viewed on February, $1^{\text {st }}$ 2014), ((2007)

6. Lutfi, Ahmad Fathullah. Fiqh Khitan Perempuan, Al-MughniPress.8, Jakarta, (2006)

7. MOH, Health Minister Regulation (Permenkes) No 163.MENKES/PERXI/2010 about Female, Law and Organization Bureau, Jakarta, (2010)

8. MOH, Health Minister Regulation (Permenkes) No. 1636 of 2010 about Female Circumcision: Ensure Security and Protection of Female Reproductive System. www. www.kesehatanibu.depkes.go.id/archives/167 (Viewed on January, 12 $2^{\text {th }}$ 2014), (2011)

9. Notoatmodjo, S. Health Promotion and Behavior Knowledge. Jakarta : Rineka Cipta, (2005)

10. Setiawati. Learning Process in Health Education, Tran Info Media, Jakarta, (2008)

11. Sunaryo. Psychology, Medical Manual Publisher. EGC, Jakarta, (2008)

12. WHO, Psychology Module to the Maternity Women Psikologi Ibu Bersalin, EGC Publisher, Jakarta, (2008)

13. WHO. Female Genital Mutilation, An Overview, Gneva, Jakarta, (2012)

14. Widayatun .T.R Behavior Knowledge, Sagung Seto, Jakarta.z (2006) 